OPEN ACCESS

Edited by:

Klaus-Holger Knorr.

University of Münster, Germany

Reviewed by:

Vincent Jassey,

UMR5245 Laboratoire Ecologie

Fonctionnelle et Environnement

(ECOLAB), France

Jason Keller,

Chapman University, United States

*Correspondence:

Line Rochefort

line.rochefort@fsaa.ulaval.ca

Specialty section:

This article was submitted to

Biogeoscience,

a section of the journal

Frontiers in Earth Science

Received: 02 July 2020

Accepted: 18 December 2020

Published: 22 April 2021

Citation:

Kim J, Rochefort L, Hogue-Hugron $S$,

Alqulaiti Z, Dunn C, Pouliot $R$,

Jones TG, Freeman $C$ and Kang $H$ (2021) Water Table Fluctuation in

Peatlands Facilitates Fungal

Proliferation, Impedes Sphagnum

Growth and

Accelerates Decomposition.

Front. Earth Sci. 8:579329.

doi: 10.3389/feart.2020.579329

\section{Water Table Fluctuation in Peatlands Facilitates Fungal Proliferation, Impedes Sphagnum Growth and Accelerates Decomposition}

\author{
Jinhyun Kim ${ }^{1}$, Line Rochefort ${ }^{2 *}$, Sandrine Hogue-Hugron ${ }^{2}$, Zuhair Alqulaiti ${ }^{3}$, Christian Dunn ${ }^{3}$, \\ Remy Pouliot ${ }^{2}$, Timothy G. Jones ${ }^{3}$, Chris Freeman ${ }^{3}$ and Hojeong Kang ${ }^{1}$ \\ ${ }^{1}$ School of Civil and Environmental Engineering, Yonsei University, Seoul, Republic of Korea, ${ }^{2}$ Peatland Ecology Research Group \\ (PERG), Centre for Northern Studies, Department of Plant Sciences, Université Laval, Québec, QC, Canada, ${ }^{3}$ School of Natural \\ Sciences, Bangor University, Bangor, United Kingdom
}

Northern peatlands are substantial carbon sinks because organic matter in peat is highly stable due to the low rate of decomposition. Waterlogged anaerobic conditions induce accumulation of Sphagnum-derived phenolic compounds that inhibit peat organic matter decomposition, a mechanism referred to as the "enzymic latch". Recent studies have predicted that the water table in northern peatlands may become unstable. We observed that such unstable water table levels can impede the development of Sphagnum mosses. In this study, we determined the effects of low and high frequency water table fluctuation regimes on Sphagnum growth and peat organic matter decomposition, by conducting a year-long mesocosm experiment. In addition, we conducted a molecular analysis to examine changes in abundance of fungal community which may play a key role in the decomposition of organic matter in peatlands. We found that rapid water table fluctuation inhibited the growth of Sphagnum due to fungal infection but stimulated decomposition of organic matter that may dramatically destabilize peatland carbon storage. Increased $\mathrm{pH}$, induced by the fluctuation, may contribute to the enhanced activity of hydrolases in peat. We demonstrated that the water table fluctuation in peatlands impeded Sphagnum growth and accelerates decomposition due to fungal proliferation. Thus, we suggested that understanding the microbial community in the northern peatlands is essential for elucidating the possible changes in carbon cycle of peatland under the changing world.

Keywords: peatland, water table fluctuation, sphagnum, fungi, enzymic latch, decomposition

\section{INTRODUCTION}

Northern peatlands are characterized by waterlogged, anaerobic, acidic, phenolic-rich, cool conditions, resulting in the low decomposition rate and high accumulation rate $\left(3-80 \mathrm{~g} \mathrm{C} \mathrm{m}^{-2}\right.$ $\mathrm{y}^{-1}$ ) of organic matter as peat (Gorham, 1991; Aerts et al., 1992; Gallego-Sala et al., 2018). Northern peatlands are recognized to impact the global $\mathrm{CO}_{2}$ budget as they occupy up to $3 \%$ (around 4 millions $\mathrm{km}^{2}$ ) of the Earth's terrestrial surface (Yu et al., 2010; Xu et al., 2018), and their peat is a substantial carbon sink where the recently estimated carbon storage was up to $1,055 \mathrm{Pg}$ (Nichols and Peteet, 2019), which is more than a half of global soil organic matter (Scharlemann et al., 2014). This 
significant C storage had been considered to continuously increase since last glaciation but now we question its potential changes in stability under changing climate (Zhang et al., 2020).

Northern bogs and muskegs are dominated by Sphagnum mosses, whose plant tissues are more recalcitrant than the plant matter of vascular plants or other mosses (Moore and Basiliko, 2006). Water table is a key controlling factor of carbon sequestration in these northern peatlands because it determines oxygen availability (Haraguchi, 1991; Belyea, 1996; Abbott et al., 2013). Waterlogged anaerobic conditions induce accumulation of Sphagnum-derived phenolic compounds due to a lack of phenol oxidase activity able to break down phenolic compounds (Abbott et al., 2013; Kim et al., 2014). The abundant phenolic compounds prevent hydrolases activity to degrade organic matter (Freeman et al., 1990; Wetzel, 1992; Freeman et al., 2001). In contrast, if water table is lowered, oxygen becomes available to activate phenol oxidative enzymes, lowering the quantity of phenolic compounds and consequently allowing the decomposition of organic matter. This mechanism is called 'enzymic latch' and it is one of the key mechanisms controlling decomposition of organic matter in peatlands (Freeman et al., 2001; Romanowicz et al., 2015; Kang et al., 2018).

Northern peatlands have the ability to self-regulate their hydrology, keeping water levels relatively stable (Rochefort and Lode, 2006). However in large peatlands (in the order of 1,000 ha or more), some have streams in the watershed. Seasonal fluctuation of water table may occur because of variation of precipitation and temperature (Okland, 1989), but it is not as substantial or as rapid as fluctuations exhibited by riverine wetlands (Junk et al., 1989). We have observed that in the proximity of these streams, Sphagnum cover thins out to give rise to a more shrubby vegetation (L. Rochefort pers. obs.). We know that Sphagnum species composition and growth is substantially dependent on water table characteristics (Sjors, 1948), and usually grow better when the water tables are stable (Clymo and Duckett, 1986; Holden et al., 2004). In the field, we have observed that frequent inundation appears unfavorable to Sphagnum establishment (Brown et al., 2017). In addition, climate changes are expected to be the most pronounced in the high latitudinal region where northern peatlands are distributed (Overland et al., 2014), thus water table levels may become less stable (Taminskas et al., 2018). These observations suggest that the role of the northern peatlands as a carbon sink would be weakened because of water table fluctuation-induced reduction of Sphagnum growth and stimulation of decomposition of organic matter by reducing the 'enzymic latch' mechanism (Min et al., 2015). While some studies have attempted to determine the effect of water table level on peatland (Trinder et al., 2008; Kwon et al., 2013; Potvin et al., 2015; Lamit et al., 2017), the effect of fluctuation frequency in a controlled environment has never been tested experimentally and mechanisms driving the responses remain unknown.

Fungi represent a major microbial group playing a fundamental role in the decomposition of phenolic compounds in peatlands (Thormann, 2006; Thormann and
Rice, 2007; Sinsabaugh, 2010). Ascomycetes, Deuteromycetes, and Basidiomycetes are the main producer of polyphenol oxidative enzymes called laccase (Bourbonnais et al., 1995; Leontievsky et al., 1997; Baldrian, 2006). In addition, fungal laccases have higher potential for the decomposition of phenolics than others (e.g., bacterial laccases) (Thurston, 1994). Thus, fungal communities may play a critical role in the 'enzymic latch' mechanism in peatlands (Romanowicz et al., 2015). Fungi in peatlands are found in peat soil, roots of vascular plant, and Sphagnum tissue. Particularly, Sphagnum itself provides habitat for pathogenic and parasitic fungi which alters growth and function of Sphagnum (Kostka et al., 2016). Water table, or oxygen availability, is likely to shift microbial community structure, including that of fungi (Freeman et al., 2001; Trinder et al., 2008). Although, previous studies have illustrated the effect of water availability on fungal communities (Jassey et al., 2018), the mechanistic responses of fungal communities and their activity to water table fluctuations are not fully understood.

The objective of this study was to determine the effects of water table fluctuation on the Sphagnum growth and decomposition of organic matter in peat. In particular, we hypothesized that 1) fluctuation-induced changes in fungal communities will inhibit the Sphagnum growth, 2) decomposition of organic matter in peat will be stimulated by water table fluctuation, and 3 ) the ability of peat as a carbon sink will be weakened by water table fluctuation. An experiment was carried out in the controlled environment of a greenhouse containing Sphagnum peat mesocosms experiencing different water table depths and fluctuation regimes. Sphagnum growth as well as peat and Sphagnum living layer chemistry, and peat microbial communities were monitored to determine if water table fluctuations affected the establishment of a Sphagnum carpet, biomass accumulation and the decomposition of Sphagnum, and to uncover the associated microbial mechanisms.

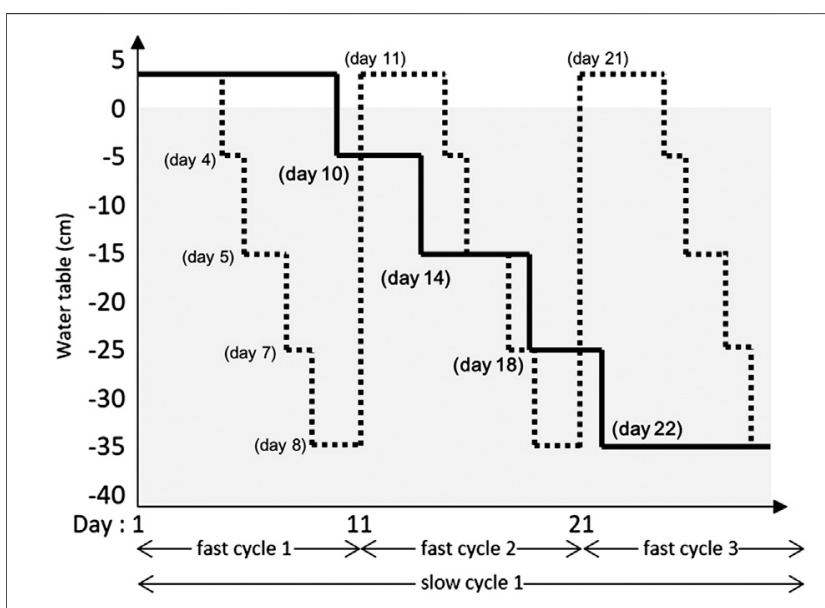

FIGURE 1 | Description of the slow fluctuating (solid line) and the fast fluctuating (dotted line) over 30 days. Positive water table values are levels above the peat surface (i.e., inundations). 


\section{MATERIALS AND METHODS}

\section{Experimental Design and Implementation}

The effect of water table (WT) fluctuation and Sphagnum species on biomass accumulation, rate of decomposition, enzymic and microbial activity were tested in a split-plot greenhouse experiment (Supplementary Figure S1). Of the three water table regimes (main plots), control involved a stable water table maintained between 0 and $-5 \mathrm{~cm}$. The two fluctuating regimes were fast and slowly fluctuating water table cycles between $+2 \mathrm{~cm}$ (inundation) and $-35 \mathrm{~cm}$ over 10 and 30 days, respectively (Figure 1). In subplots, three Sphagnum species from three different subgenera were tested: 1) S. fallax (Cuspidata), 2) S. medium (Sphagnum; Hassel et al., 2018) S. fuscum (Acutifolia). All treatment combinations were replicated four times, in four blocks accounting for possible micro-climatic differences present in the Université Laval greenhouse.

This experiment was carried out in large mesocosms measuring $110 \mathrm{~cm}$ (length) $\times 72 \mathrm{~cm}$ (width) $\times 100 \mathrm{~cm}$ (height) (Supplementary Figure S1). Each mesocosm was equipped with an individual system of drains and pipes connected to a reservoir that allowed individual control of water table at the desired level. The irrigation system was designed to create groundwater discharge from a $15 \mathrm{~cm}$ layer of sand at the base of the mesocosms, which then moved upwards through $35 \mathrm{~cm}$ of fibric commercial peat (von post $\mathrm{H} 2-3$ ). Rain water was distributed by hydrostatic pressure from the reservoir to the base of the mesocosm via one perforated inlet pipe coated with nylon. A pipe perforated every $5 \mathrm{~cm}$, connected to the inlet pipe, located outside of each mesocosm allowed manipulation of water table by adding or removing plastic plugs.

Sphagnum plant material was collected by hand in a natural peatland $\left(46^{\circ} 46^{\prime} \mathrm{N} ; 71^{\circ} 00^{\prime} \mathrm{N}\right)$. Only the first $10 \mathrm{~cm}$ of the moss carpet was collected, as this fraction of the moss possesses the highest regeneration capacity (Campeau and Rochefort, 1996). Sphagnum was sorted from other plant species and the moss carpet was broken apart into fragments. Sphagnum fragments were then spread in a $1 \mathrm{~cm}$ thick uniform layer covering $100 \%$ of the peat surface. Each mesocosm was divided into three sections (each section measuring $72 \mathrm{~cm}$ (length) $\times 37 \mathrm{~cm}$ (width) with clear fiberglass sheets inserted in the top $5 \mathrm{~cm}$ of peat, preventing the dispersion of Sphagnum beyond its experimental unit, while allowing water circulation. In main plots with fluctuating water tables, the Sphagnum layer was covered with a nylon net to prevent displacement of the fragments. After plant spreading, fragments were grown in ideal conditions for 5 weeks: stable water table maintained at $-10 \mathrm{~cm}$ with watering every two days. Following this acclimatization period, the five different water regimes were implemented over 360 days; i.e., 12 slow fluctuating cycles and 36 fast fluctuating cycles. During the course of the experiment, all mesocosms were abundantly watered with rainwater once every 10 days, at day \#1 of each fast fluctuating cycle. Any vascular plant found growing in the experiment was removed. Over the course of the experiment, the growing conditions varied according to the season. Over winter, spring, and fall, daily temperature and relative humidity were maintained at $21^{\circ} \mathrm{C}$ and $60 \%$ respectively while nightly conditions were maintained at $15^{\circ} \mathrm{C}$ and $70 \%$. Over summer, daily temperatures and $\mathrm{RH}$ varied between $23-26^{\circ} \mathrm{C}$ and $44-59 \%$ respectively, while nightly conditions varied between $19-21^{\circ} \mathrm{C}$ and $68-84 \%$.

\section{Monitoring \\ Hydrological Parameters}

Over the duration of the experiment, the position of the water table in the mesocosm was recorded every 2-3 days, prior to manipulation of the water table. Over a period of 60 days, two (slowly fluctuating) or six (rapidly fluctuating) cycles were imposed, soil moisture was recorded every 2-3 days with a W.E.T Sensor and $\mathrm{HH} 2$ Moisture Meter (Delta-T Devices, Cambridge, United Kingdom).

\section{Vegetation}

Prior to manipulation of the water table, 15 litter bags ( 5 per species), were inserted vertically into the upper $5 \mathrm{~cm}$ of the peat surface, for a total of 300 bags in the 20 mesocosms. To prepare the litter bags, a small portion of the three Sphagnum species harvested was sorted individually and placed in a pre-weighed nylon mesh bags $(5 \mathrm{~cm} \times 7.5 \mathrm{~cm}$; mesh gauge of $0.25 \mathrm{~mm})$ and weighed until a constant mass was obtained. Between 0.5 and $2 \mathrm{~g}$ of Sphagnum fibers were inserted into each bag. The 100 bags containing $S$. fallax were inserted under the $S$. fallax subplots and the same was performed for the two other Sphagnum species. At the end of the experiment, the litter bags were retrieved, cleaned and weighed until constant mass. The linear mass loss $\left(\mathrm{k}^{\prime}\right)$ over the duration of the experiment was calculated following the equation (Reader and Stewart, 1972):

$$
\mathrm{k}^{\prime}=\frac{\mathrm{X}_{0}-\mathrm{X}}{\mathrm{X}} \times 100
$$

(where $\mathrm{X}_{0}$ represents the initial dry Sphagnum mass (g) and $\mathrm{X}$ is the final dry Sphagnum mass (g) after incubation in the mesocosms).

At the end of the experiment, all plant material (mostly Sphagnum, but also some other bryophytes) was collected down to the commercial peat layer and dried at $70^{\circ} \mathrm{C}$ until constant mass. A subset of the biomass samples, approximately $25 \%$, was sorted prior to drying to separate Sphagnum biomass from the other mosses. The ratio between the known cover of non-Sphagnum mosses and its mass was used to adjust the weight of the unsorted samples.

Sphagnum covered-area (\%) of each mesocosms were measured, and the reduction of Sphagnum covered-area compared to control treatments was determined as response ratio calculated by natural $\log$ of values from treatment and control $(\ln$ (treatment/control)).

\section{Chemical Analyses of Sphagnum Living Layer}

Sphagnum biomass subsamples from each mesocosm were dried and analyzed for determining the content of total carbon (C), total nitrogen $(\mathrm{N})$, phosphate $\left(\mathrm{PO}_{4}{ }^{3-}\right)$, nitrate $\left(\mathrm{NO}_{3}{ }^{-}\right)$, ammonium $\left(\mathrm{NH}_{4}^{+}\right)$, and sulfate $\left(\mathrm{SO}_{4}{ }^{2-}\right)$. Analysis of $\mathrm{C}$ and $\mathrm{N}$ 


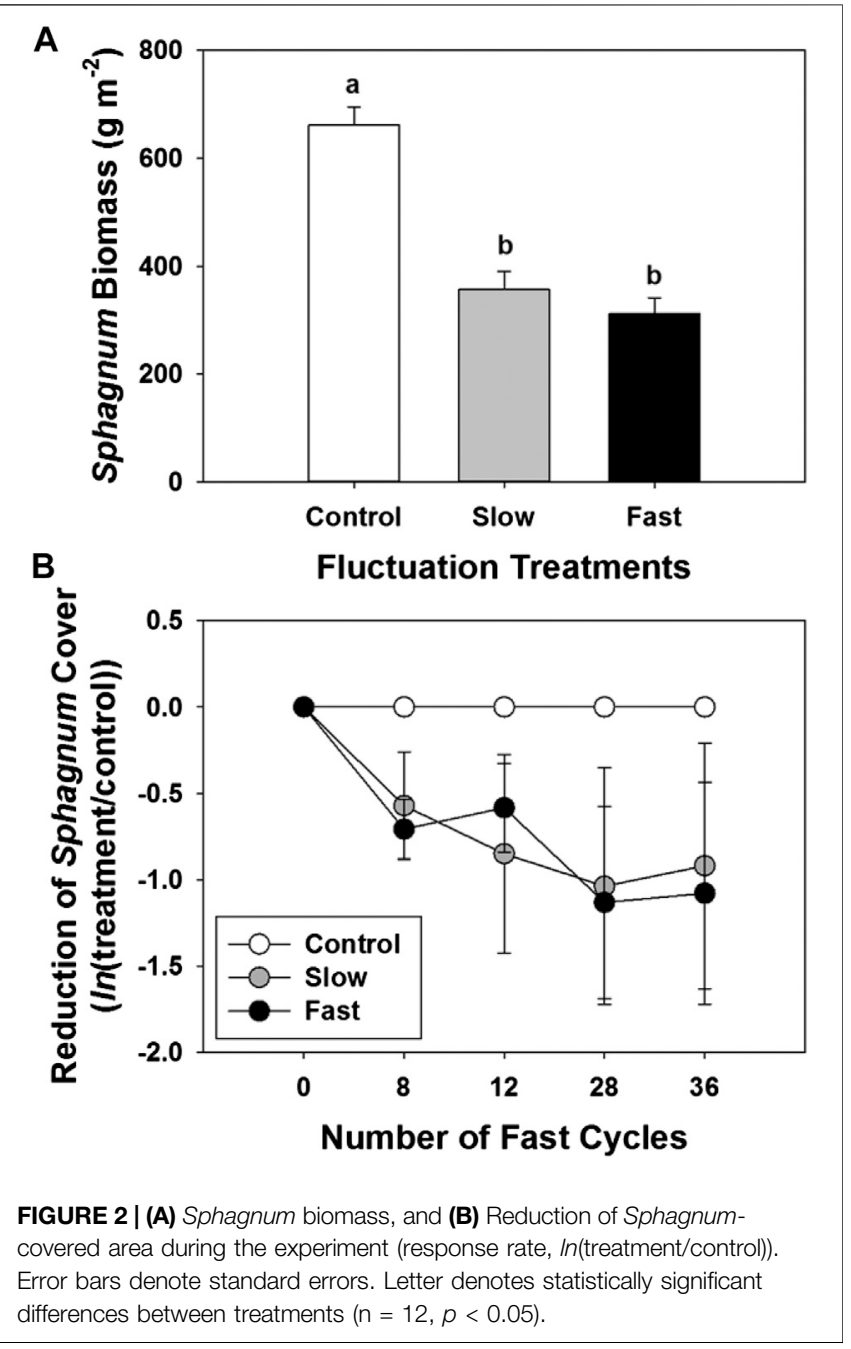

were carried out with a Leco TruMac CNS analyser, while $\mathrm{PO}_{4}{ }^{3-}$, $\mathrm{NO}_{3}{ }^{-}, \mathrm{NH}_{4}{ }^{+}$and $\mathrm{SO}_{4}{ }^{2-}$ was extracted by $1 \mathrm{M} \mathrm{KCl}$ and measured by flow injection using a Quikchem 8,500 series 2 FIA system.

\section{Phenolics and Extracellular Enzyme Activity}

At the end of the experiment, peat samples were collected per subplots by using peat corer (length $8 \mathrm{~cm}$ and diameter $4 \mathrm{~cm}$ ). The corer and all instruments used to collect the samples were washed in isopropylic alcohol and rinsed with distilled water in between each samples. The samples were placed in a fridge overnight and sent to Bangor University for analyses the following day (in a freezer with icepacks) by express shipment (3 days).

Activities of extracellular enzymes ( $\beta$-glucosidase, Xylosidase, $\mathrm{N}$-acetyl-glucosaminidase, Arylsulfatase, and Phosphatase) were measured by using methylumbelliferyl (MUF)-substrates (see Freeman et al. (1995) and Kang and Freeman (1999) for detailed method). Extracellular enzymes were extracted from peat samples with acetate buffer $(50 \mathrm{mM}, \mathrm{pH} 5.0)$. The extracted solution was mixed with MUF-substrates and incubated for $1 \mathrm{~h}$ at $25^{\circ} \mathrm{C}$. Then the intensities of fluorescence of the solution were measured by fluorometer (Molecular Devices M2e Spectramax plate-reader (wavelength accuracy $2 \mathrm{~nm}$, photometric accuracy 0.006, photometric precision 0.003 ) at $460 \mathrm{~nm}$ emission and $355 \mathrm{~nm}$ excitation. The water-soluble phenolics were extracted by distilled water and the concentration was measured by colorimetric method with Folin Ciocalteau phenol reagent (Box, 1983; Dunn et al., 2013).

\section{Molecular Analyses}

The peat and Sphagnum samples for microbial analysis were collected and stored at $-80^{\circ} \mathrm{C}$. Microbial DNA was extracted by using DNeasy PowerSoil Kit (Qiagen, Germany) from $400 \mathrm{mg}$ of peat and $200 \mathrm{mg}$ of Sphagnum samples. Then, we performed real-time quantitative PCR to quantify the abundance of bacteria, fungi, and fungal laccase gene. The primer sets, experimental procedure, and PCR protocol are in the supplementary materials.

\section{Statistical Analyses}

The differences in Sphagnum biomass, decomposition rates, Sphagnum chemistries, extracellular enzyme activities, and abundances of microbes and functional genes among the treatments were analyzed with one-way ANOVA. Spearman method was used to determine the correlations between the measurements. All statistical analyses were conducted by using SPSS 23 (SPSS inc., Chicago, IL, United States) and (R Core Team, 2019).

\section{RESULTS}

\section{Sphagnum Biomass and Chemistry}

After almost one full year of growth, accumulated Sphagnum biomass, including living and dead, was $46-53 \%$ lower in the fluctuation treatments than under stable water levels (control) (Figure 2A). The area of Sphagnum-covered peat was continually reduced by $42-52 \%$ during the experiment in the fluctuation treatments compared to the control of more stable water table although it was statistically not significant (Figure 2B). Results of biomass and covered area indicated that the growth of Sphagnum was reduced if the water table was fluctuating. The near-surface stable water table $(0$ to $-5 \mathrm{~cm})$ resulted in the greatest accumulation of biomass.

Water table fluctuation also altered chemical properties of Sphagnum tissue. Especially, $\mathrm{PO}_{4}{ }^{3-}$ (71-78\%), $\mathrm{NO}_{3}{ }^{-}$(50-51\%), and $\mathrm{C} / \mathrm{N}$ ratio $(21-28 \%)$ were significantly reduced in the fluctuation WT treatments (Table 1).

TABLE 1 | Chemical properties of Sphagnum living layer. Letter denotes statistically significant differences between treatments (Mean \pm Standard Error, $\mathrm{n}=12, \mathrm{p}<0.05)$.

\begin{tabular}{|c|c|c|c|c|c|}
\hline $\begin{array}{l}\text { Fluctuation } \\
\text { treatments }\end{array}$ & $\begin{array}{l}\mathrm{SO}_{4}{ }^{2-} \\
(\mathrm{ppm})\end{array}$ & $\begin{array}{l}\mathrm{PO}_{4}{ }^{3-} \\
(\mathrm{ppm})\end{array}$ & $\begin{array}{l}\mathrm{NH}_{4}^{+} \\
\text {(ppm) }\end{array}$ & $\begin{array}{l}\mathrm{NO}_{3}^{-} \\
(\mathrm{ppm})\end{array}$ & $\begin{array}{l}\mathrm{C} / \mathrm{N} \\
\text { ratio }\end{array}$ \\
\hline Control & $125 \pm 18$ & $213 \pm 22 \mathbf{a}$ & $19 \pm 0.5 \mathbf{a}$ & $230 \pm 73$ & $66 \pm$ \\
\hline Slow & $143 \pm 32$ & $60 \pm 7 \mathbf{b}$ & $16 \pm 0.4 \mathbf{b}$ & $111 \pm 20$ & $52 \pm 2 \mathbf{b}$ \\
\hline Fast & $108 \pm 13$ & $45 \pm 3 \mathbf{b}$ & $16 \pm 0.3 \mathbf{b}$ & $113 \pm 25$ & $47 \pm 1 \mathbf{b}$ \\
\hline
\end{tabular}




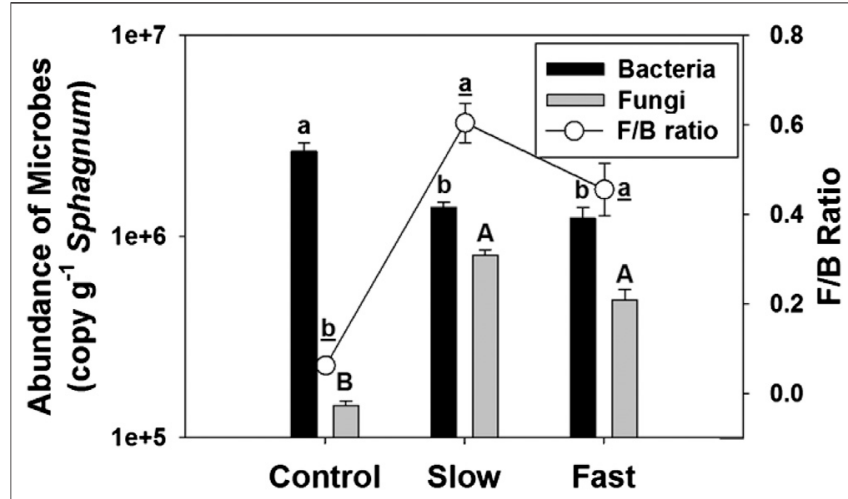

FIGURE 3 | Abundance of fungi (fungal ITS) and bacteria (bacterial 16S rRNA) (bar), and F/B ratio (line) on Sphagnum surface. Letter denotes statistically significant differences between treatments $(n=24, p<0.05)$.

\section{Abundance of Fungi on the Sphagnum Surface}

The abundance of fungi on the Sphagnum surface significantly increased by $236-459 \%$ in the fluctuating WT treatments (Figure 3), and we have visually observed the fungal invasion in the fluctuation treatments (Supplementary Figure S2). In contrast, the abundance of bacteria decreased by $47-54 \%$ in the fluctuating WT treatments, which results substantially higher F/B ratio in the fluctuating WT treatments than in controlled stable WT (Figure 3). Abundance of fungi $(r=-0.425, \mathrm{p}=0.010)$ and $\mathrm{F} / \mathrm{B}$ ratio $(\mathrm{r}=-0.377, \mathrm{p}=0.023)$ had significant negative correlation with Sphagnum biomass, supporting that proliferation of fungi may reduce Sphagnum growth (Supplementary Figure S3).

\section{Decomposition Rate and Biogeochemistry of Peat}

The decomposition rate measured by litter bag method was significantly enhanced by $74-79 \%$ in the fluctuating WT treatments (Figure 4). Higher decomposition resulted in lower Sphagnum biomass and covered-area (Supplementary Figure S3).

Among the five extracellular enzymes ( $\beta$-glucosidase, $\beta$-Xylosidase, $\mathrm{N}$-acetyl- $\beta$-glucosaminidase, Arylsulfatase, and Phosphatase), the activity of phosphatase significantly increased while the activity of $\mathrm{N}$-acetyl- $\beta$-glucosaminidase decreased within the mesocosms of fluctuating WT treatments (Table 2). Decomposition rate exhibited a significant positive correlation $(\mathrm{r}=0.481, \mathrm{p}=0.003)$ with the activity of phosphatase (Supplementary Figure S3).

Peat $\mathrm{pH}$ significantly increased by $1.7-4.6 \%$ with higher frequency water table fluctuations, fast fluctuation showing the highest $\mathrm{pH}$ value (Table 3). Concentrations of phenolics significantly decreased by $18-31 \%$ with intensity of water table fluctuation, fast fluctuation showing the lowest concentration of phenolics (Table 3). Concentrations of phenolics were negatively correlated with phosphatase $(\mathrm{r}=-0.929, p<0.001)$ while $\mathrm{pH}$ was positively correlated with phosphatase $(\mathrm{r}=0.877, p<0.001)$ (Supplementary Figure S3).

\section{Abundance of Fungi in Peat}

The abundance of fungal laccase gradually tended to increase with increasing intensity of water table fluctuation, fast fluctuation showed the highest abundance of fungal laccase (Figure 5). Meanwhile, content of fungal laccase to total fungi significantly increased (Figure 5).

\section{'Enzymic Latch' Mechanism}

The conceptual diagram of 'enzymic latch' mechanism clearly showed that the mechanism was significantly involved in the changes in decomposition rate by water table fluctuation (Figure 6). According to Figure 6, the increased abundance of fungi by water table fluctuation consequently reduced the concentration of phenolics, which allowed hydrolases to be activated. Then, decomposition was stimulated by the higher activity of hydrolases. Sphagnum itself have a significant positive correlation to the concentration of phenolics, which supported that it might regulate its phenolic content and then the antimicrobial effects on hydrolases. Peat $\mathrm{pH}$ significantly positively related to the activity of hydrolases, especially phosphatase.

\section{DISCUSSION}

\section{Suppressed Sphagnum Growth Through Fungal Infection}

The results showed that both Sphagnum biomass and Sphagnumcovered area were substantially reduced by water fluctuation (Figures 2A,B), suggesting strongly that the water table fluctuation, regardless of whether fluctuations were slow or fast, impeded growth and development of Sphagnum. We had

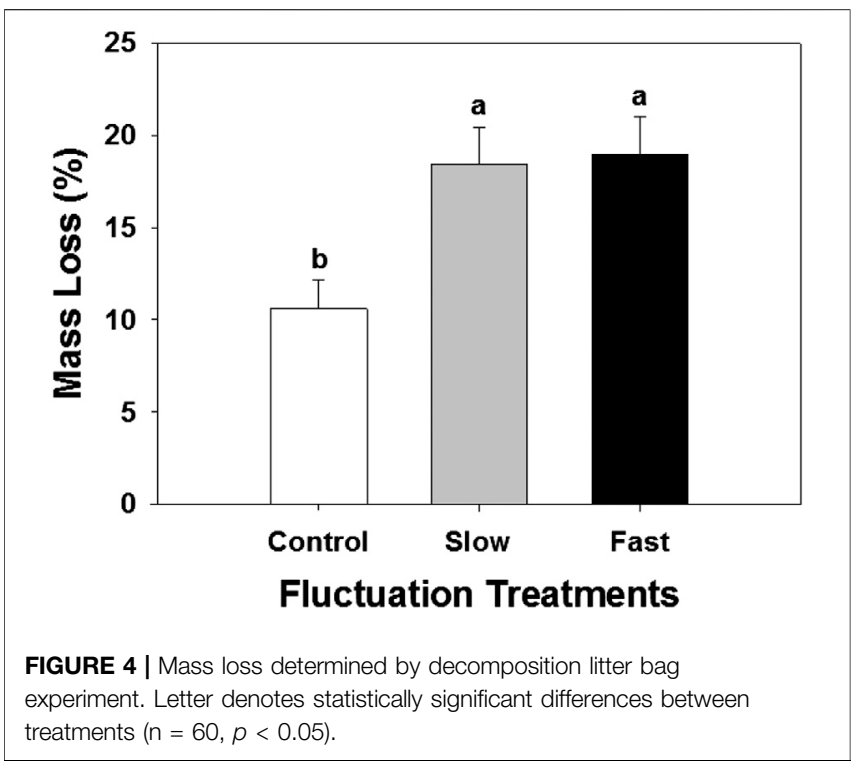


TABLE 2 | Activities of extracellular enzymes in peat. Letter denotes statistically significant differences between treatments $(\mathrm{n}=12, p<0.05)$.

\begin{tabular}{|c|c|c|c|c|c|}
\hline \multirow[t]{2}{*}{ Fluctuation treatments } & \multicolumn{5}{|c|}{ Activities $\left(\mathrm{nmol} \mathrm{g}^{-1}\right.$ peat $\mathrm{min}^{-1}$ ) } \\
\hline & $\beta$-glucosidase & $\beta$-xylosidase & $\mathrm{N}$-acetyl- $\beta$-glucosaminidase & Arylsulfatase & Phosphatase \\
\hline Control & $8.1 \pm 0.8$ & $3.4 \pm 0.4$ & $1.8 \pm 0.1 \mathbf{a}$ & $0.2 \pm 0.04$ & $4.1 \pm 0.1 \mathbf{c}$ \\
\hline Slow & $7.9 \pm 0.4$ & $3.4 \pm 0.2$ & $1.6 \pm 0.1 \mathbf{b}$ & $0.3 \pm 0.03$ & $6.3 \pm 0.3 \mathbf{b}$ \\
\hline Fast & $8.3 \pm 0.5$ & $3.8 \pm 0.3$ & $1.6 \pm 0.04 \mathbf{a b}$ & $0.2 \pm 0.04$ & $13.6 \pm 1.4 \mathbf{a}$ \\
\hline
\end{tabular}

TABLE 3 | pH and concentration of phenolics in peat. Letter denotes statistically significant differences between treatments $(n=12,0<0.05)$.

\begin{tabular}{|c|c|c|}
\hline Fluctuation treatments & pH & $\begin{array}{c}\text { Phenolics } \\
\text { (mg g }{ }^{-1} \text { peat) }\end{array}$ \\
\hline Control & $4.10 \pm 0.02 \mathbf{b}$ & $15.5 \pm 0.8 \mathbf{a}$ \\
\hline Slow & $4.17 \pm 0.02 \mathbf{b}$ & $12.7 \pm 0.7 \mathbf{b}$ \\
\hline Fast & $4.29 \pm 0.01 \mathbf{a}$ & $10.6 \pm 0.4 \mathbf{b}$ \\
\hline
\end{tabular}
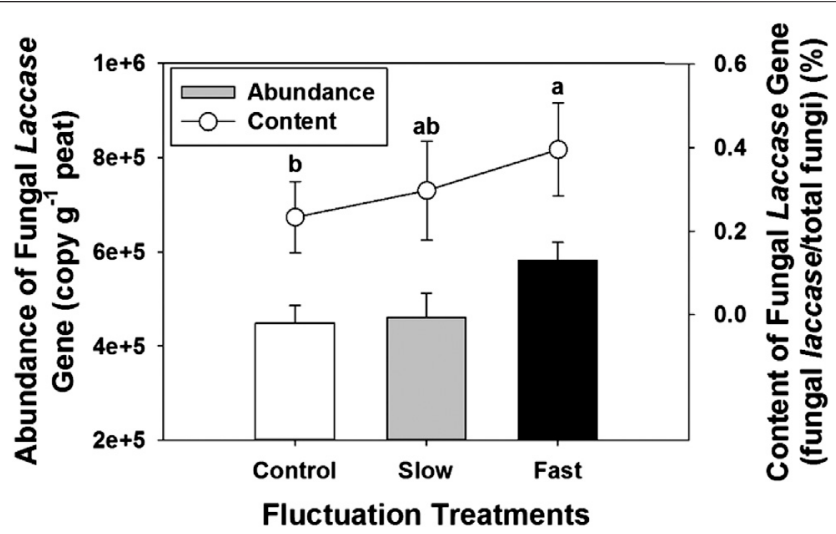

FIGURE 5 | Abundance of fungal laccase gene (bar) and content of fungal laccase gene to the total fungi (line) in peat. Error bars denote standard errors. Letter denotes statistically significant differences between treatments $(\mathrm{n}=24, p<0.05)$.

hypothesized that fluctuation-induced fungal infection would reduce Sphagnum growth which was supported by visual (Supplementary Figure S2) and analytical evidences (Figure 3). In particular, F/B ratio significantly increased indicating that the fungal community became dominant under the water table fluctuation treatments (Figure 3). Many pathogenic fungi (e.g., Scleroconidioma sphagnicola, Acremonium cf. curvulum, and Oidiodendron maius for Sphagnum fuscom, Lyophyllum palustre for Sphagnum fallax, and Discinella schimperi for Sphagnum squarrosum etc.) can invade cell wall, chlorophyllose cells, and cortical cells of leaf and stem of Sphagnum (Untiedt and Mller, 1985; Redhead and Spicer, 1981; Tsuneda et al., 2001a; Tsuneda et al., 2001b), resulting in the deformation of cells. The infection of pathogenic fungi generally attacks a specific type of cell and reduces its functioning but does not usually result total destruction of its Sphagnum host in pristine peatlands.

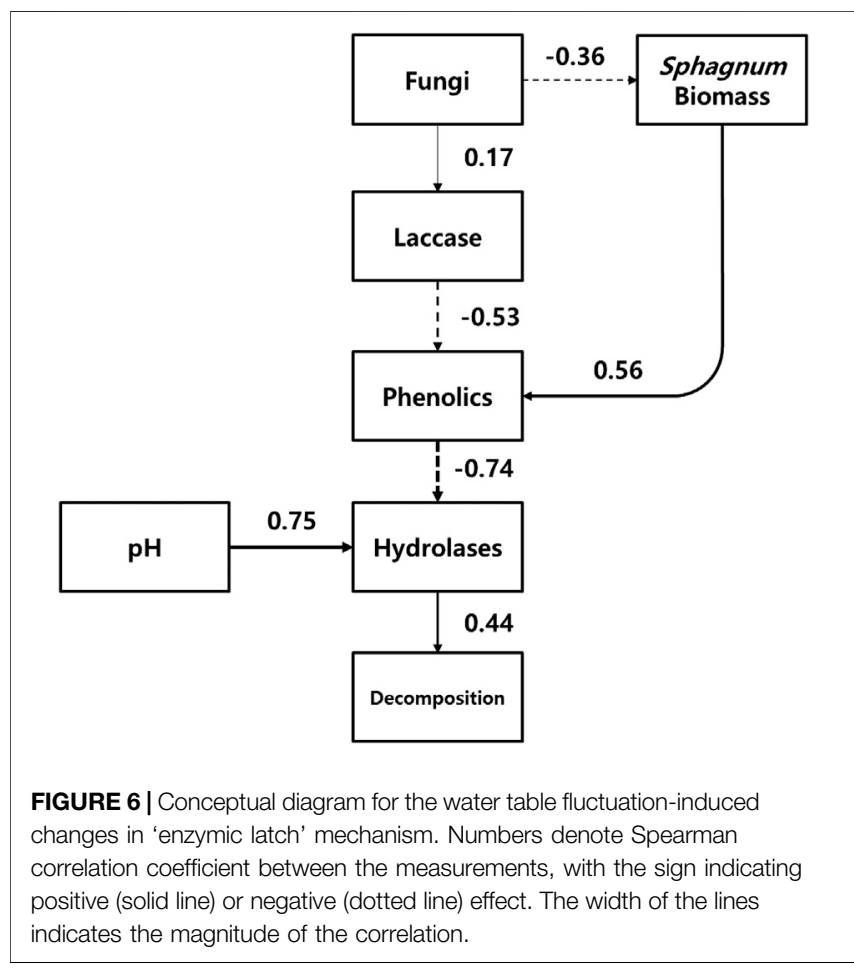

However, the growth of Sphagnum was substantially inhibited by fungal infection in our experimental case.

Water table fluctuation treatments in our experiment were

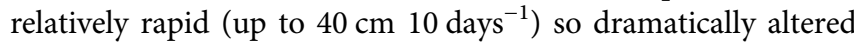
growth of three Sphagnum species. Since, Sphagnum mosses are sensitive to water availability, insufficient water availability due to rapid water table fluctuation can result in poor growth and even irreversible desiccation (Schipperges and Rydin, 1998; Potvin et al., 2015). The deprived nutrient conditions of Sphagnum tissues in the fluctuation treatments (Table 1), appears to render Sphagnum mosses more vulnerable to fungal infection under the water table fluctuation treatments. In contrast to the Sphagnum mosses, the growth of fungi was stimulated in the fluctuation treatments (Figure 3). For fungi, low water availability generally promotes more favourable aerobic conditions (Deacon, 1997; Trinder et al., 2008), except extremely dry conditions (Laiho, 2006; Jaatinen et al., 2007). The combined effect of reduced water availability to Sphagnum mosses and enhanced fungal infection inhibited growth and development of Sphagnum mosses in the both fluctuation treatments. In addition, no substantial impeded Sphagnum 
growth and fungal proliferation were observed in the lower stable water table treatments (Supplementary Figures S4,S5), which supported that the water table fluctuation plays a pivotal role in the proposed responses.

Although the three Sphagnum species used in this study grow optimally at different water table levels $(0 \sim-5 \mathrm{~cm}$ for $S$. fallax, $-10 \sim-15 \mathrm{~cm}$ for $S$. medium, $-20 \sim-25 \mathrm{~cm}$ for $S$. fuscum), the responses of all three species were identical in our experiment. We assumed that the intensity of water table fluctuation was too high to separate the responses of different Sphagnum species. In future study, subdivided level of water table fluctuation should be applied to differentiate the distinctive responses of different Sphagnum species.

\section{Stimulated Decomposition of Organic Matter}

Water table fluctuation significantly stimulated decomposition of organic matter (Figure 4). Several studies confirm that improved peat aeration can eliminate decomposition-restriction mechanism by phenolics (Freeman et al., 2001), resulting in enhanced hydrolase activity. In this experimental setup, the 'enzymic latch' mechanism is shown to play a key role to the increasing decomposition rate under rapid water table fluctuation (Figure 6), supported by the strong negative correlation between the concentration of phenolics and the activity of hydrolases, particularly phosphatase $(\mathrm{r}=-0.74$, $p<0.05$, Supplementary Figure S3). Romanowicz et al. (2015) reported that water table level significantly affected phosphatase activity excluding other hydrolases, and Kang and Freeman (1999) reported that phosphatase had the greatest sensitivity for water table condition. The abundance of fungal laccase gradually increased with higher frequency of the water table fluctuation (Figure 5), which may have contributed to the decomposition of phenolics (Thurston, 1994; Romanowicz et al., 2015). Besides, our experimental water table fluctuations may have directly decreased the concentration of phenolics (as well as other nutrients) by net leaching, potentially contributing to the observed stimulation of phosphatase activity.

In our experiment, $\mathrm{pH}$ might also play a critical role in controlling the 'enzymic latch' mechanism under water table fluctuation (Figure 6). The activity of total hydrolases was also strongly related to $\mathrm{pH}$ (Figure 6) because the activity of phosphatase had substantial positive correlation to $\mathrm{pH}$ (Supplementary Figure S3). Since, acid-phosphatase is dominant in northern peatlands and its optimum $\mathrm{pH}$ is near 5 (Kay, 1932), increasing in $\mathrm{pH}$ from 4.10 to 4.29 (on a log scale) by water table fluctuation is likely to enhance the activity of phosphatase (Table 3). In addition, $\mathrm{pH}$ may directly affect microbial community, thus contribute to stimulated decomposition of organic matter (Kang et al., 2018).

Changes in the chemistry of Sphagnum living layer might also affected decomposition rates. The $\mathrm{C} / \mathrm{N}$ ratio of Sphagnum living layer is typically high, and peatlands are generally nitrogendeficient environment (Thormann et al., 2001). In our experiment, rapid water table fluctuation decreased $\mathrm{C} / \mathrm{N}$ ratio of Sphagnum tissue making Sphagnum living layer more easily decomposed (Manzoni et al., 2008), while more nitrogen is released, creating a nitrogen source for surrounding decomposers so stimulate their activity. Decreases in $\mathrm{C} / \mathrm{N}$ ratio (i.e., decreases in carbon content) may be due to changing carbon allocation of Sphagnum by water table fluctuation. Since Sphagnum with water stress invests more carbon to respiration and essential house-keeping processes rather than secondary processes such as production of phenolics, cell-wall formation, and reproduction, water table fluctuation-induced drier condition may decrease the amount of phenolics released by Sphagnum (Jassey et al., 2011). Therefore, water table fluctuation may reduce the inhibitory effect of phenolics and enhance the decomposition rate by decreasing phenolics from Sphagnum.

\section{Reduced Carbon Sequestration Ability of Peat by the Water Table Fluctuation}

Overall, the water table fluctuation reduced carbon sequestration in peat through two different mechanisms: 1) inhibiting Sphagnum growth and 2) stimulating decomposition of organic matter. Sphagnum growth was substantially inhibited by lowered water availability and enhanced fungal infection, reducing carbon sequestration through photosynthesis. Decomposition of organic matter in peat was significantly stimulated because the decomposition-restricting 'enzymic latch' mechanism had weakened, thereby reducing carbon sequestration. These two mechanisms may dramatically compromise the capacity of peatlands to act as a carbon sink.

Our original hypothesis, that water table fluctuation would inhibit the growth of Sphagnum and accelerate the decomposition rate of organic matter in peat, was confirmed by a manipulation experiment of water table in peat. Particularly, fungal infection plays a key role in the inhibition of Sphagnum growth while $\mathrm{pH}$ may plays a key role in the controlling of decomposition of organic matter in peat.

\section{Implications}

In recent decades, there has been an increasing interest in developing the production of Sphagnum biomass as a renewable resource in Sphagnum farms (Campeau and Rochefort, 2002; Pouliot et al., 2015; Gaudig et al., 2018). Brown et al., 2017 recently pointed to the importance of maintaining stable moisture peat substrate conditions to support Sphagnum growth and $\mathrm{CO}_{2}$ sink functions. Consequently, if Sphagnum biomass production is in future to be significantly enhanced, serious consideration must be given to managing a stable water table levels within the Sphagnum farm peat fields. Our study clearly indicates that optimal biomass production will only be achieved under a regime of limited water table fluctuation.

In this mesocosm study, we demonstrated that the water table fluctuation in peatlands impeded Sphagnum growth and accelerated decomposition due to fungal proliferation, which consequently compromises the capacity of peatlands to act as a carbon sink. The changes in peatland hydrology and biogeochemistry substantially alter the function of peatland, and microbial activity was deeply involved in the processes. Predicting the effects of global climate change on the carbon cycle of northern peatlands is one of the key objectives of peatland researchers because the global climate change is expected to be 
the greatest in the high latitudinal regions (e.g., changes in water table level and stability). However, most current prediction models do not consider microbial processes and microbial community structures as input data, which increases the uncertainty of the model prediction because of the overlooked contribution of microbial activity. Here, we suggested that microbial information should be accounted for in the predictions in order to elucidate the future of the northern peatland in the changing world.

\section{DATA AVAILABILITY STATEMENT}

The raw data supporting the conclusions of this article will be made available by the authors, without undue reservation.

\section{AUTHOR CONTRIBUTIONS}

JK contributed to the microbial analysis, data curation, preparation of the original draft, revision of the manuscript. The conceptualization of the study, designing and performing the greenhouse experiment, and analysis of Sphagnum were conducted by LR and SH-H. ZA, CD, and TJ contributed to soil chemistry and enzyme analysis. RP, CF, and HK contributed to the interpretation of data and critical review of the draft.

\section{REFERENCES}

Abbott, G. D., Swain, E. Y., Muhammad, A. B., Allton, K., Belyea, L. R., Laing, C. G., et al. (2013). Effect of water-table fluctuations on the degradation of Sphagnum phenols in surficial peats. Geochim. Cosmochim. Acta 106, 177-191. doi:10. 1016/j.gca.2012.12.013

Aerts, R., Wallen, B., and Malmer, N. (1992). Growth-limiting nutrients in Sphagnum-dominated bogs subject to low a high atmospheric nitrogen supply. J. Ecol. 80, 131-140. doi:10.2307/2261070

Baldrian, P. (2006). Fungal laccases-occurrence and properties. FEMS Microbiol. Rev. 30, 215-242. doi:10.1111/j.1574-4976.2005.00010.x

Belyea, L. R. (1996). Separating the effects of litter quality and microenvironment on decomposition rates in a patterned peatland. Oikos. 77, 529-539. doi:10. 2307/3545942

Bourbonnais, R., Paice, M. G., Reid, I. D., Lanthier, P., and Yaguchi, M. (1995). Lignin oxidation by laccase isozymes from Trametes versicolor and role of the mediator 2,2'-azinobis(3-ethylbenzthiazoline-6-sulfonate) in kraft lignin depolymerization. Appl. Environ. Microbiol. 61 (5), 1876-1880. doi:10.1128/ AEM.61.5.1876-1880.1995

Box, J. D. (1983). Investigation of the Folin-Ciocalteau phenol reagent for the determination of polyphenolic substances in natural waters. Water Res. 17 (5), 511-525. doi:10.1016/0043-1354(83)90111-2

Brown, C., Strack, M., and Price, J. S. (2017). The effects of water management on the CO2 uptake of Sphagnum moss in a reclaimed peatland. Mires Peat. 20 (5), 1-15. doi:10.19189/MaP.2016.OMB.258

Campeau, S., and Rochefort, L. (2002). "Possibilities and limits to Sphagnum farming," in Proceedings of the international peat symposium: peat in horticulture - Quality and environmental challenges. A joint symposium of commission II (Industrial utilization of peat and peatlands) and commission V (After-use of cut-over peatlands) of the international peat society, Pärnu, Estonia, September 3-6, 2002. Editors G. Schmilewski and L. Rochefort (Jyväskylä, Finland: International Peat Society), 264-269.

Campeau, S., and Rochefort, L. (1996). Sphagnum regeneration on bare peat surfaces: field and greenhouse experiments. J. Appl. Ecol. 33, 599-608. doi:10.2307/2404988

\section{FUNDING}

The running of this experiment at the Université Laval greenhouse was supported by a NSERC Discovery grant to Line Rochefort (No. 1380972012) and a Canadian Foundation for Innovation grant. The analyses of samples were supported by funds from the Ministry of Education of Korea (2020R1I1A2072824) and the Ministry of Science and ICT of Korea (2018K2A9A1A01090455, 2019K1A3A1A74107424, 2019K1A3A1A80113041). JK is supported by the funds from the Ministry of Education of Korea (2019R1A6A3A01091184).

\section{ACKNOWLEDGMENTS}

JK thanks to the '2019 International Joint Research Grant' funded by Graduate School of Yonsei University. We thank Richard Belanger for providing lab space and resources for microbial analysis, Talal Asif for photos and comments on the final draft, and Jeongeun Yun for the helps in statistical analysis and revision of the manuscript.

\section{SUPPLEMENTARY MATERIAL}

The Supplementary Material for this article can be found online at: https://www.frontiersin.org/articles/10.3389/feart.2020.579329/ full\#supplementary-material.

Clymo, R. S., and Duckett, J. G. (1986). “The ecology of Sphagnum," in Bryophyte ecology. Editor A. J. E. Smith (London: Chapman \& Hall), 229-289.

Deacon, J. W. (1997). Modern mycology. Oxford: Blackwell Publishing.

Dunn, C., Jones, T. G., Girard, A., and Freeman, C. (2013). Methodologies for extracellular enzyme assays from wetland soils. Wetlands. 34, 9-17. doi:10.1007/s13157-013-0475-0

Freeman, C., Liska, G., Ostle, N. J., Jones, S. E., and Lock, M. A. (1995). The use of fluorogenic substrates for measuring enzyme activity in peatlands. Plant Soil. 175, 147-152. doi:10.1007/BF02413020

Freeman, C., Lock, M. A., Marxsen, J., and Jones, S. E. (1990). Inhibitory effects of high molecular weight dissolved organic matter upon metabolic processes in biofilms from contrasted rivers and streams. Freshw. Biol. 24, 159-166. doi:10.1021/acs.est.9b04105

Freeman, C., Ostie, N., and Kang, H. (2001). An enzymic 'latch' on a global carbon store - a shortage of oxygen locks up carbon in peatlands by restraining a single enzyme. Nature. 409, 149. doi:10.1038/35051650

Gallego-Sala, A. V., Charman, D. J., Brewer, S., Page, S. E., Prentice, I. C., Friedlingstein, P., et al. (2018). Latitudinal limits to the predicted increase of the peatland carbon sink with warmin. Nat. Clim. Change. 8, 907-913. doi:10.1038/s41558-018-0271-1

Gaudig, G., Krebs, M., Prager, A., Wichmann, S., Barney, M., Caporn, S. J. M., et al. (2018). Sphagnum farming from species selection to the production of growing media: a review. Mires Peat. 20 (13), 1-30. doi:10.19189s/MaP.2018.OMB.340

Gorham, E. (1991). Northern Peatlands: role in the carbon cycle and probable responses to climatic warming. Ecol. Appl. 1, 182-195. doi:10.2307/1941811

Haraguchi, A. (1991). Effects of water-table oscillation on redox property of peat in a floating mat. J. Ecol. 79, 1113-1121. doi:10.2307/2261102

Hassel, K., Kyrkjeeide, M. O., Yousefi, N., Prestø, T., Stenøien, H. K., Shaw, J. A., et al. (2018). Sphagnum divinum (sp. nov.) and S. medium Limpr. and their relationship to S. magellanicum. Brid. J. Bryol. 40, 197-222. doi:10.1080/03736687.2018.1474424

Holden, J., Chapman, P., and Labadz, J. (2004). Artificial drainage of peatlands: hydrological and hydrochemical process and wetland restoration. Prog. Phys. Geogr. 28, 95-123. doi:10.1191/0309133304pp403ra

Jaatinen, K., Fritze, H., Laine, J., and Laiho, R. (2007). Effects of short- and long-term waterlevel drawdown on the populations and activity of aerobic decomposers in a boreal peatland. Global Change Biol. 12, 491-510. doi:10.1111/j.1365-2486.2006.01312.x

Jassey, V. E. J., Chiapusio, G., Gilbert, D., Buttler, A., Toussaint, M.-L., and Binet, P. (2011). Experimental climate effect on seasonal variability of polyphenol/ 
phenoloxidase interplay along a narrow fen-bog ecological gradient in Sphagnum fallax. Global Change Biol. 17, 2945-2957. doi:10.1111/j.13652486.2011.02437.x

Jassey, V. E. J., Reczuga, M. K., Zielinska, M., Stowinska, S., Robroek, B. J. M., Mariotte, P., et al. (2018). Tipping point in plant-fungal interactions under severe drought causes abrupt rise in peatland ecosystem respiration. Global Change Biol. 24, 972-986. doi:10.1111/gcb.13928

Junk, W. J., Bayley, P. B., and Sparks, R. E. (1989). "The flood-pulse concept in riverfloodplain systems," in Proceedings of the international large river symposium (MARS), Canadian journal of fisheries and aquatic sciences special publications 106. Editor D. P. Dodge (Ottawa: NRC Research Press), 110-127.

Kang, H., and Freeman, C. (1999). Phosphatase and arylsulphatase activities in wetland soils: annual variation and controlling factors. Soil Biol. Biochem. 31, 449-454. doi:10.1016/S0038-0717(98)00150-3

Kang, H., Kwon, M. J., Kim, S., Lee, S., Jones, T. G., Johncock, A. C., et al. (2018). Biologically driven DOC release from peatlands during recovery from acidification. Nat. Commun. 9, 3807. doi:10.1038/s41467-018-06259-1

Kay, H. D. (1932). Phosphatase in growth and disease of bone. Physiol. Rev. 12, 384-422. doi:10.1152/physrev.1932.12.3.384

Kim, S., Kim, Y., Kim, Y., Kim, K., Wang, S., Kang, H., et al. (2014). Effects of planting method and nitrogen addition on Sphagnum growth in microcosm wetlands. Paddy Water Environ. 12, 185-192. doi:10.1007/s1033-014-0427-1

Kostka, J. E., Weston, D. J., Glass, J. B., Lilleskov, E. A., Shaw, A. J., and Turetsky, M. R. (2016). The Sphagnum microbiome: new insights from an ancient plant lineage. New Phytol. 211, 57-64. doi:10.1111/nph.13993

Kwon, M. J., Haraguchi, A., and Kang, H. (2013). Long-term water regime differentiates changes in decomposition and microbial properties in tropical peat soils exposed to the short-term drought. Soil Biol. Bioghem. 60, 33-44. doi:10.1016/j.soilbio.2013.01.023

Laiho, R. (2006). Decomposition in peatlands: reconciling seemingly contrasting results on the impacts of lowered water tables. Soil Biol. Biochem. 38, 2024. doi:10.1016/j.soilbio.2006.02.017

Lamit, L. J., Romanowicz, K. J., Potvin, L. R., Rivers, A. R., Singy, K., Lennon, J. T., et al. (2017). Patterns and drivers of fungal community depth stratification in Sphagnum peat. FEMS Microbiol. Ecol. 93, fix082. doi:10.1093/femsec/fix082

Leontievsky, A., Myasoedova, N., Pozdnyakova, N., and Golovleva, L. (1997). 'Yellow' laccase of Panus tigrinus oxidizes non-phenolic substrates without electron-transfer mediators. FEBS Lett. 413 (3), 446-448. doi:10.1016/S0014-5793(97)00953-8

Manzoni, S., Jackson, R. B., Trofymow, J. A., and Porporato, A. (2008). The global stoichiometry of litter nitrogen mineralization. Science. 321, 684-686. doi:10. 1126/science.1159792

Min, K., Freeman, C., Kang, H., and Choi, S. U. (2015). The regulation by phenolic compounds of soil organic matter dynamics under a changing environment. Biomed Res. Int. 2015, 825098. doi:10.1155/2015/825098

Moore, T., and Basiliko, N. (2006). Decomposition in Boreal Peatlands. In Wieder, R. K., and Vitt, D. H. (eds) Boreal Peatland Ecosystems. Ecological Studies (Analysis and Synthesis). Vol 188, Springer, Berlin, Heidelberg. doi:10.1007/ 978-3-540-31913-9_7

Nichols, J. E., and Peteet, D. M. (2019). Rapid expansion of northern peatlands and doubled estimate of carbon storage. Nat. Geosci. 12, 917-921. doi:10.1038/s41561-019-0454-z

Okland, R. H. (1989). A phytoecological study of the mire Northern Kisselbergmosen, SE Norway. I. Introduction, flora, vegetation and ecological conditions. Sommerfeltia. 8, 1-172. doi:10.1111/j.1756-1051.1990.tb01755.x

Overland, J. E., Wang, M., Walsh, J. E., and Stroeve, J. C. (2014). Future arctic climate changes: adaptation and mitigation time scales. Earths Future. 2, 68-74. doi:10.1002/2013EF000162

Potvin, L. R., Kane, E. S., Chimner, R. A., Kolka, R. K., and Lilleskov, E. A. (2015). Effects of water table position and plant functional group on plant community, aboveground production, and peat properties in a peatland mesocosm experiment (PEATcosm). Plant Soil. 387, 277-294. doi:10.1007/s11104-014-2301-8

Pouliot, R., Hugron, S., and Rochefort, L. (2015). Sphagnum farming: a long-term study on producing peat moss biomass sustainably. Ecol. Eng. 74, 135-147. doi:10.1016/j.ecoleng.2014.10.007

R Core Team (2019). R: a language and environment for statistical computing. Vienna, Austria: R Foundation for Statistical Computing.

Reader, R. J., and Stewart, J. M. (1972). The relationship between net primary production and accumulation for a peatland in southeastern Manitoba. Ecology. 53 (6), 1024-1037. doi:10.2307/1935415
Redhead, S. A., and Spicer, K. W. (1981). Discinella schimperi, a circumpolar parasite of Sphagnum squarrosum, and notes on Bryophytomyces sphagni. Mycologia. 73, 904-913. doi:10.2307/3759801

Rochefort, L., and Lode, E. (2006). "Restoration of degraded boreal peatlands," in Boreal peatland ecosystems. Editors R. K. Weider and D. H. Vitt (Berlin: Springer), 381-423.

Romanowicz, K. J., Kane, E. S., Potvin, L. R., Daniels, A. L., Kolka, R. K., and Lilleskov, E. A. (2015). Understanding drivers of peatland extracellular enzyme activity in the PEATcosm experiment: mixed evidence for enzymic latch hypothesis. Plant Soil. 397, 371-386. doi:10.1007/s11104-015-2746-4

Scharlemann, J. P. W., Tanner, E. V. J., Hiederer, R., and Kapos, V. (2014). Global soil carbon: understanding and managing the largest terrestrial carbon pool. Carbon Manag. 5, 81-91. doi:10.4155/cmt.13.77

Schipperges, B., and Rydin, H. (1998). Response of photosynthesis of Sphagnum species from contrasting microhabitats to tissue water content and repeated desiccation. New Phytol. 140, 667-684. doi:10.1046/j.1469-8137.1998.00311.x

Sinsabaugh, R. L. (2010). Phenol oxidase, peroxidase and organic matter dynamics of soil. Soil Biol. Biochem. 42, 391-404. doi:10.1016/j.soilbio.2009.10.014

Sjors, H. (1948). Myrvegetation i Bergslagen. Acta Phytogeogr. Suecica. 21, 1-299.

Taminskas, J., Linkeviciene, R., Simanauskiene, R., Jukna, L., Kibirstis, G., and Tamkeviciute, M. (2018). Climate change and water table fluctuation: implications for raised bog surface variability. Geomorphology. 304, 40-49. doi:10.1016/j.geomorph.2017.12.026

Thormann, M. N. (2006). "The role of fungi in boreal Peatlands," in Boreal Peatland ecosystems. Editors R. K. Weider and D. H. Vitt (Berlin: Springer), 101-123.

Thormann, M. N., Bayley, S. E., and Currah, R. S. (2001). Comparison of decomposition of belowground and aboveground plant litters in peatlands of boreal Alberta, Canada. Can. J. Bot. 79, 9-22. doi:10.1139/b00-138

Thormann, M. N., and Rice, R. V. (2007). Fungi from peatlands. Fungal Divers 24, 241-299.

Thurston, C. F. (1994). The structure and function of fungal laccases. Microbiology. 140, 19-26. doi:10.1099/13500872-140-1-19

Trinder, C. J., Johnson, D., and Artz, R. R. (2008). Interactions among fungal community structure, litter decomposition and depth of water table in a cutover peatland. FEMS Microbiol. Ecol. 64, 433-448. doi:10.1111/j.1574-6941.2008.00487.x

Tsuneda, A., Chen, M. H., and Currah, R. S. (2001b). Characteristics of a disease of Sphagnum fuscum caused by Scleroconidioma sphagnicola. Can. J. Bot. 79, 1217-1224. doi:10.1139/b01-102

Tsuneda, A., Thormann, M. N., and Currah, R. S. (2001a). Modes of cell-wall degradation of Sphagnum fuscum by Acremonium cf. curculum and Oidiodendron maius. Can. J. of Bot. 79, 93-100. doi:10.1139/b00-149

Untiedt, E., and Mller, K. (1985). Colonization of Sphagnum cells by Lyophyllum palustre. Can. J. Bot. 63, 757-761. doi:10.1139/b85-095

Wetzel, R. G. (1992). Gradient-dominated ecosystems: sources and regulatory functions of dissolved organic matter in freshwater ecosystems. Hydrologia. 229, 181-198. doi:10.1007/BF00007000

$\mathrm{Xu}$, J., Morris, P. J., Liu, J., and Holden, J. (2018). PEATMAP: refining estimates of global peatland distribution based on a meta-analysis. Catena. 160, 134-140. doi:10.1016/j.catena.2017.09.010

Yu, Z., Loisel, J., Brosseau, P., Beilman, D. W., and Hunt, S. J. (2010). Global peatland dynamics since the last glacial maximum. Geophys. Res. Lett. 37, L13402. doi:10.1029/2010GL043584

Zhang, H., Väliranta, M., Piilo, S., Amesbury, M. J., Aquino-López, M. A., Roland, T. P., et al. (2020). Decreased carbon accumulation feedback driven by climateinduced drying of two southern boreal bogs over recent centuries. Global Change Biol. 26 (4), 2435-2448. doi:10.1111/gcb.15005

Conflict of Interest: The authors declare that the research was conducted in the absence of any commercial or financial relationships that could be construed as a potential conflict of interest.

Copyright (๑ 2021 Kim, Rochefort, Hogue-Hugron, Alqulaiti, Dunn, Pouliot, Jones, Freeman and Kang. This is an open-access article distributed under the terms of the Creative Commons Attribution License (CC BY). The use, distribution or reproduction in other forums is permitted, provided the original author $(s)$ and the copyright owner(s) are credited and that the original publication in this journal is cited, in accordance with accepted academic practice. No use, distribution or reproduction is permitted which does not comply with these terms. 